\title{
PENGARUH PENGGUNAAN MUSIK DALAM MODEL PEMBELAJARAN QUANTUM LEARNING TERHADAP HASIL BELAJAR FISIKA PESERTA DIDIK
}

\author{
Ummu Kalsum ${ }^{1, a}$, Mutmainna ${ }^{2, b}$, Sri Harmintin ${ }^{3, c}$ \\ 1,2,3 Universitas Sulawesi Barat

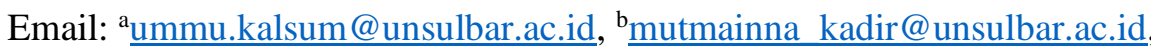 \\ ckartikasrijayanti914@gmail.com
}

\begin{abstract}
Abstrak
Penelitian ini bertujuan untuk mengetahui hasil belajar fisika peserta didik yang diajar dengan Model Pembelajaran Quantum Learning Menggunakan Musik, hasil belajar fisika peserta didik yang diajar dengan Model Pembelajaran Langsung dan perbedaan yang signifikan hasil belajar fisika peserta didik antara kelas eksperimen dan kelas kontrol. Jenis penelitian yang digunakan adalah Quasi-experimental dengan desain Nonequivalent Control Group Design. Populasi dalam penelitian ini adalah seluruh peserta didik kelas XI MIA SMA Negeri 1 Alu yang berjumlah 53 orang peserta didik. Sampel yang diteliti sebanyak 26 peserta didik yang dipilih dengan teknik Purposive Sampling. Instrumen pengumpulan data berbentuk tes essay. Data dianalisis dengan menggunakan analisis deskriptif dan inferensial. Hasil penelitian menunjukkan bahwa hasil belajar fisika peserta didik yang diajar dengan Model Pembelajaran Quantum Learning Menggunakan Musik berada pada kategori sedang. Sedangkan yang diajar dengan Model Pembelajaran Langsung berada pada kategori rendah. Dari hasil Uji T dengan taraf signifikan 5\% diperoleh (nilai $\mathrm{t}_{\text {hitung }}=3,341>\mathrm{t}_{\text {tabel }} 2,01$ ). Hal ini bermakna bahwa terdapat perbedaan signifikan antara kelas eksperimen dan kelas kontrol.
\end{abstract}

Kata kunci: Model Quantum Learning, Musik, Hasil Belajar

\section{THE EFFECT OF MUSIC USE IN QUANTUM LEARNING LEARNING MODEL ON STUDENT PHYSICS LEARNING OUTCOMES}

\begin{abstract}
The purpose of the research is to find out the value of students in learning physics using Quantum Learning Model by Music, the value of students in learning by using models directly and there was significant difference with the students value in learning physics between experimental class and control class. The kinds of research used were Quasi experimental with Nonequivalent Control Group Design. The population of the research is all students of SMA Negeri 1 Alu, eleventh grade of MIA, with the number 53 students. The sample consisted of 26 students chosen by using purposive sampling technique. The instrument of collected data was from an essay. The data analyzed showed that the value of students in learning physics using Quantum Learning by music was on category of medium. Meanwhile students who were taught by a directly learning model were in the category of law. From the experiment with the level significant $5 \%$ is getting (value $t_{\text {himus }}=3,341>t_{\text {ubod }} 2,01$ ). It means that there is a significant difference between experimental class and control class.
\end{abstract}

Keywords: Quantum Learning Model, Music, Result of Learning

\section{PENDAHULUAN}

Pembelajaran yang melibatkan guru dan peserta didik hendaknya mengacu pada peningkatan aktivitas dan partisipasi peserta didik. Tugas guru bukan semata-mata mengajar (teacher centered), akan tetapi lebih kepada bepusat pada peserta didik (student centered). Olehnya itu, guru dituntut untuk terampil dan kreatif dalam menggunakan metode pembelajaran sehingga pencapaian hasil belajar peserta didik sesuai dengan yang diharapkan. 
Selain faktor metode pembelajaran yang digunakan oleh guru, hasil belajar juga dipengaruhi oleh partisipasi peserta didik dalam proses pembelajaran. Jika peserta didik aktif dalam proses pembelajaran, maka tidak hanya aspek kognitif saja yang dapat dicapai melainkan aspek lainnya seperti aspek afektif, aspek psikomotorik dan aspek sosial juga turut berpengaruh. Untuk itu, guru sebagai fasilitator diharapkan mampu mendorong peserta didik untuk lebih aktif dalam proses pembelajaran.

\section{Pada umumnya terdapat beberapa permasalahan yang mewarnai proses pembelajaran khususnya pada mata pelajaran fisika. Salah satunya adalah kurangnya keterlibatan peserta didik sehingga berdampak pada rendahnya hasil belajar. Berdasarkan hasil wawancara dengan guru mata pelajaran fisika diketahui bahwa nilai rata-rata yang diperoleh peserta didik kelas XI MIA tergolong masih rendah. Hal ini dapat dilihat dari capaian hasil belajar fisika peserta didik pada nilai ujian semester tahun ajaran 2018/2019. Hasil capaian tersebut menunjukkan bahwa 17 dari 26 peserta didik memperoleh hasil belajar di bawah nilai KKM. Untuk mata pelajaran Fisika sendiri, nilai KKM yang ditentukan oleh pihak sekolah sebesar 70,00. [1].}

Hasil observasi lebih lanjut diketahui bahwa rendahnya hasil belajar peserta didik disebabkan oleh beberapa faktor diantaranya, Peserta didik cenderung menghafal rumus dan mengerjakan soal sehingga peserta didik kurang mengetahui aplikasi dalam kehidupan sehari-hari, Dalam penyampaian materi, guru lebih sering menggunakan metode ceramah sehingga peserta didik merasa jenuh selama pembelajaran berlangsung, Selama proses pembelajaran, peserta didik kurang aktif dalam menerima materi. Hal tersebut diungkapkan langsung oleh guru bidang studi bahwa sebagian besar peserta didik berada dalam kategori kurang aktif, dan Sebagian peserta didik beranggapan bahwa fisika itu sulit. Hal ini diketahui dari hasil wawancara terhadap peserta didik kelas XI MIA.

Salah satu upaya untuk mengatasi permasalahan di atas yaitu dengan menerapkan model pembelajaran Quantum Learning. Model pembelajaran Quantum Learning sangat berbeda dengan model pembelajaran lain.
Disamping model pembelajaran Quantum Learning dikembangkan untuk mencapai hasil belajar akademik, model pembelajaran Quantum Learning juga dianggap efektif karena peserta didik dapat menerima pelajaran dengan kecepatan yang mengesankan dan dibarengi kegembiraan. [2]

Pada Prinsipnya, Quantum Learning berakar dari upaya Dr. Georgi Lozanov, seorang pendidik berkebangsaan Bulgaria yang melakukan eksperimen mengenai "suggestology" (sugesti). Hasil eksperimennya menunjukkan bahwa sugesti dapat mempengaruhi hasil situasi belajar baik melalui pemberian sugesti positif maupun negatif. Beberapa teknik yang digunakan untuk memberikan sugesti positif adalah mendudukkan murid secara nyaman, memasang musik latar di dalam kelas, meningkatkan partisipasi individu dan memotivasi peserta didik. [2]

Penerapan model pembelajaran Quantum Learning terhadap hasil belajar dikaji dengan judul penelitian Penerapan Model Pembelajaran Quantum Learning dengan Media Flashcard untuk Meningkatkan Motivasi dan Hasil Belajar Peserta didik Kelas X di SMA NEGERI 1 Purwoharjo-Banyuwangi Tahun Pelajaran 2011/2012 (Pada Pokok Bahasan Animalia). Dari penelitian tersebut, menunjukkan bahwa terjadi peningkatan hasil belajar peserta didik setelah diterapkan model pembelajaran Quantum Learning. [3]

Dalam mengimplementasikan model Quantum Learning, dipilih salah satu media yaitu dengan menggunakan musik. Hal ini dilakukan agar pembelajaran Quantum Learning lebih optimal. Pada dasarnya musik merupakan suatu kebutuhan bagi sebagian besar remaja, karena dengan mendengarkan musik seseorang dapat menjadi senang, gembira, nyaman dan dapat menurunkan tingkat kejenuhan. Penelitian tentang pengaruh musik terhadap tingkat kejenuhan dilakukan dengan judul Efektivitas music klasik (Mozart) untuk menurunkan kejenuhan belajar peserta didik kelas XI SMAN 4 Yogyakarta. Hasil penelitiannya menunjukkan bahwa musik klasik (Mozart) berpengaruh positif terhadap penurunan tingkat kejenuhan belajar pada peserta didik kelas XI SMAN 4 Yogyakarta. [4] 
Selain itu, musik juga memberikan suasana yang ramah, mengurangi stress dan meningkatkan konsentrasi belajar saat pembelajaran berlangsung. Penelitian yang serupa tentang pengaruh musik untuk meningkatkan konsentrasi belajar dilakukan dengan judul penelitian PENGARUH PENGGUNAAN MUSIK TERHADAP KONSENTRASI BELAJAR ANAK SEKOLAH $D A S A R$. Berdasarkan hasil penelitiannya menunjukkan bahwa musik memiliki pengaruh positif terhadap konsentrasi belajar peserta didik [5].

Musik juga dapat meningkatkan motivasi belajar peserta didik, hal ini diungkap oleh dalam penelitian yang berjudul Penggunaan media pembelajaran melalui musik instrumental untuk meningkatkan motivasi belajar peserta didik kelas XI di Madrasah Aliyah Bustanul Makmur Banyuwangi. Berdasarkan hasil penelitiannya diketahui bahwa penggunaan media pembelajaran musik instrumental dapat meningkatkan motivasi belajar peserta didik. Pencapaian ini ditinjau dari penggunaan musik yang dapat meminimalisir kejenuhan dan ketidak nyamanan peserta didik dalam belajar. Peserta didik terlihat antusias, tertarik dengan apa yang disampaikan oleh guru dan dapat mengekspresikan dirinya tanpa merasa ada beban. [6]

Hal ini berarti bahwa dengan mengaitkan musik dalam pembelajaran akan mampu membuat peserta didik menjadi lebih bersemangat untuk belajar dan mampu merangsang otak untuk bekerja. Salah satu penelitian terkait dengan pengaruh musik terhadap hasil belajar adalah penelitian dengan judul penelitian Pengaruh Musik Klasik Terhadap Hasil dan Aktivitas Belajar Matematika Peserta didik Kelas VII di SMPN 2 Kota Bengkulu. Berdasarkan hasil penelitiannya menunjukkan bahwa musik dapat mempengaruhi hasil belajar peserta didik. [7]

Berdasarkan kajian penelitian terkait antara Quantum Learning dan musik terhadap hasil belajar maka peneliti berinisiatif untuk memadukan model pembelajaran Quantum Learning dengan media pembelajaran musik. Tujuan paduan ini untuk mengetahui dampak penerapannya terhadap hasil belajar.

\section{METODE}

\section{Jenis dan Desain Penelitian}

Jenis Penelitian ini adalah penelitian Quasi-Eksperimen dengan desain nonequivalent control group design.

$\begin{array}{ccc}\mathrm{O}_{1} & \mathrm{X} & \mathrm{O}_{2} \\ \mathrm{O}_{3} & & \mathrm{O}_{4}\end{array}$

\section{Teknik Analisis Data \\ Penilaian Model Pembelajaran}

Analisis penilaian ini dimaksudkan untuk memberikan gambaran mengenai hasil pelaksanaan pada setiap tahap-tahap Model Pembelajaran Quantum Learning Menggunakan Musik. Keterlaksanaan Model Pembelajaran Quantum Learning Menggunakan Musik dapat diketahui dengan menggunakan rumus sebagai berikut:

Nilai $=\frac{\sum \text { Penilaian tiap Aspek }}{\sum \text { Aspek }}$

Kriteria Penilaian Model Pembelajaran ditunjukkan pada tabel berikut.

Tabel 1 Kriteria Penilaian Model

Pembelajaran Quantum Learning Menggunakan Musik

\begin{tabular}{cc}
\hline Nilai & Kriteria \\
\hline $98<\mathrm{SB} \leq 100$ & Sangat Baik \\
\hline $80<\mathrm{B} \leq 90$ & Baik \\
\hline $70<\mathrm{C} \leq 80$ & Cukup \\
\hline$\leq 70$ & Kurang \\
\hline &
\end{tabular}

\section{Penilaian Hasil belajar fisika}

Penilaian ini bertujuan untuk memberikan gambaran mengenai hasil belajar peserta didik setelah diajar dengan menerapkan model pembelajaran Quantum Learning Menggunakan Musik. Rumus yang digunakan dalam analisis deskriptif untuk penelitian ini adalah: 
Menghitung rata-rata $(\underline{X})$

$\underline{X}=\frac{\sum f_{i} x_{i}}{\sum f_{i}}$

Standar deviasi / Simpangan baku (S)

$$
S=\sqrt{\frac{\sum(X-\underline{X})^{2}}{(n)}}
$$

Berikut disajikan tabel kategori hasil belajar fisika (kognitif) peserta didik.

Tabel 2 Kategori Hasil Belajar Kognitif Peserta Didik

\begin{tabular}{ccc}
\hline No & $\begin{array}{c}\text { Interval } \\
\text { nilai }\end{array}$ & Keterangan \\
\hline 1. & $<70$ & Rendah \\
\hline 2. & $72-81$ & Sedang \\
\hline 3. & $82-90$ & Tinggi \\
\hline 4. & $91-100$ & Sangat Tinggi \\
\hline \multicolumn{3}{c}{ (SMA Negeri 1 Alu) [10] }
\end{tabular}

\section{Uji Normalitas}

Uji normalitas digunakan untuk mengetahui apakah data yang diteliti berasal dari populasi yang berdistribusi secara normal atau tidak. Normalitas data diuji menggunakan rumus sebagai berikut:

$$
\chi^{2}=\frac{\sum\left(O_{i}-E_{i}\right)^{2}}{E_{i}}
$$

Keterangan:

$\chi^{2}:$ Chi Kuadrat

$o_{i}$ : Frekuensi hasil pengamatan

$E_{i}$ : Frekuensi diharapkan (teori) $\mathrm{dk}=\mathrm{k}-1$

Dengan kriteria pengujian normalitas dengan $\alpha=0,05$

Jika $\chi_{\text {hitung }}^{2} \geq \chi_{\text {tabel }}^{2}$ maka data tidak berdistribusi normal

Jika $\chi_{\text {hitung }}^{2}<\chi_{\text {tabel }}^{2}$ maka data berdistribusi normal

\section{Uji Homogenitas}

Untuk pengujian homogenitas dari skor hasil belajar peserta didik digunakan uji $\mathrm{F}$ dengan analisis menggunakan aplikasi SPSS for windows versi 20,0. Kriteria pengujian homogenitas bila $\chi^{2}{ }_{\text {hitung }}<\chi_{\text {tabel }}^{2}$ pada taraf signifikan $\alpha=0,05$.

\section{Uji N-Gain}

Uji N-Gain dilakukan untuk melihat peningkatan yang terjadi sebelum dan sesudah pembelajaran dengan menggunakan rumus:

$\mathrm{G}=\frac{\text { skor }_{\text {post }}-\text { skor }_{\text {pre }}}{\text { skor }_{\text {maks }}-\text { skor }_{\text {pre }}}$

Keterangan:

$\mathrm{S}_{\text {pre: }}$ Skor total pada tes awal

$\mathrm{S}_{\text {post }}$ : Skor total pada tes akhir

$\mathrm{S}_{\text {maks }}$ : Skor maksimum

Tabel 3 Kategori Tingkat N-Gain

\begin{tabular}{cc}
\hline Batasan & Kategori \\
\hline $\mathrm{g}>0,3$ & Rendah \\
\hline $0,3 \leq \mathrm{g} \leq 0,7$ & Sedang \\
\hline $\mathrm{G}<0,7$ & Tinggi \\
\hline
\end{tabular}

[11]

\section{Uji Hipotesis}

Uji hipotesis dilakukan untuk menjawab rumusan hipotesis penelitian. Pengujian hipotesis pada penelitian ini dengan menggunakan uji-t, dengan $\alpha=0,05$.

$t_{\text {hitung }}=\frac{x_{1}-x_{2}}{\sqrt{\frac{s_{1}{ }^{2}}{n_{1}}+\frac{s_{2}}{n_{2}}}}$

Keterangan:

$x_{1}$ : Skor rata-rata kelas eksperimen

$x_{2}$ : Skor rata-rata kelas kontrol

$\mathrm{S}_{1}$ : Simpangan baku kelas eksperimen

$\mathrm{S}_{2}$ : Simpangan baku kelas kontrol

$\mathrm{n}_{1}$ : Jumlah sampel kelas eksperimen

$\mathrm{n}_{2}$ : Jumlah sampel kelas kontrol

Dengan kriteria pengujian untuk $\mathrm{t}$ adalah:

$\mathrm{t}_{\text {hitung }} \leq \mathrm{t}_{\text {tabel }}$, maka $\mathrm{H}_{\mathrm{a}}$ ditolak dan $\mathrm{H}_{0}$ diterima $t_{\text {hitung }}>t_{\text {tabel }}$, maka $\mathrm{H}_{\mathrm{a}}$ diterima dan $\mathrm{H}_{0}$ ditolak

Dengan hipotesis penelitian sebagai berikut:

Ho: $\mu=\mu_{0}$

На $: \mu \neq \mu_{0}$

Keterangan :

$\mu_{0}$ : Rata-rata Hasil Belajar menggunakan Model Pembelajaran Quantum Learning menggunakan Musik 
$\mu$ : Rata-rata Hasil Belajar menggunakan Model Pembelajaran Langsung

$H_{0}$ : Tidak terdapat perbedaan Hasil Belajar yang signifikan pada peserta didik kelas XI MIA SMA Negeri 1 Alu antara kelas yang menggunakan Model Pembelajaran Quantum Learning Menggunakan Musik dan Model Pembelajaran Langsung.
$H_{a}$ :Terdapat perbedaan hasil belajar yang signifikan pada peserta didik kelas XI MIA SMA Negeri 1 Alu antara kelas yang menggunakan Model Pembelajaran Quantum Learning Menggunakan Musik dan Model Pembelajaran Langsung.

\section{HASIL DAN DISKUSI}

Tabel 4 Hasil Analisis Deskriptif Pretest Hasil Belajar Kognitif Kelas Eksperimen

Eksperimen

\begin{tabular}{ccc} 
Skor & Pretest & Posttest \\
\hline Skor tertinggi & 57 & 89 \\
\hline Skor terendah & 28 & 65 \\
\hline Skor ideal & 108 & 108 \\
\hline Rata-rata & 43,38 & 79,12 \\
\hline Standar Deviasi & 7,56 & 6,24 \\
\hline
\end{tabular}

Tabel 5 Data Pretest Hasil Belajar Kognitif Fisika Peserta Didik Kelas Eksperimen

\begin{tabular}{cccc}
\hline $\begin{array}{c}\text { Interval } \\
\text { Nilai }\end{array}$ & $\begin{array}{c}\text { Jumlah Peserta } \\
\text { Didik }\end{array}$ & $\mathrm{P}(\%)$ & Kategori \\
\hline$<70$ & 26 & 100 & Rendah \\
\hline $72-81$ & 0 & 0 & Sedang \\
\hline $82-90$ & 0 & 0 & Tinggi \\
\hline $91-100$ & 0 & 0 & Sangat Tinggi \\
\hline Jumlah & 26 & 0 & \\
\hline
\end{tabular}

Tabel 6 Data Posttest Hasil Belajar Kognitif Fisika Peserta Didik Kelas Kontrol

\begin{tabular}{cccc}
\hline Interval Nilai & $\begin{array}{c}\text { Jumlah Peserta } \\
\text { Didik }\end{array}$ & $\mathrm{P}(\%)$ & Kategori \\
\hline$<70$ & 27 & 100 & Rendah \\
\hline $72-81$ & 0 & 0 & Sedang \\
\hline $82-90$ & 0 & 0 & Tinggi \\
\hline $91-100$ & 0 & 0 & Sangat Tinggi \\
\hline Jumlah & 27 & 100 & \\
\hline
\end{tabular}

Tabel 7 Hasil Uji Normalitas Pretest dan Posttest Hasil Belajar Kognitif Fisika Peserta Didik

\begin{tabular}{ccccc}
\hline No. & Data & $\begin{array}{c}\text { Jumlah } \\
\text { Sampel }\end{array}$ & $\begin{array}{c}\chi^{2} \text { hitung } \\
<\chi^{2} \text { tabel }\end{array}$ & $\begin{array}{c}\text { Kesimp } \\
\text { ulan }\end{array}$ \\
\hline 1 & $\begin{array}{c}\text { Hasil belajar pretest } \\
\text { kelas eksperimen }\end{array}$ & 26 & $\begin{array}{c}3,06<11, \\
0705\end{array}$ & Normal \\
\hline 2 & $\begin{array}{c}\text { Hasil belajar posttest } \\
\text { kelas eksperimen }\end{array}$ & 26 & $\begin{array}{c}9,02<11, \\
0705\end{array}$ & Normal \\
\hline 3 & Hasil belajar pretest & 27 & $\begin{array}{c}1,89<11, \\
0705\end{array}$ & Normal \\
\hline \multirow{2}{*}{4} & kelas kontrol & 27 & $\begin{array}{c}8,95<11, \\
0705\end{array}$ & Normal \\
\hline
\end{tabular}


Tabel 8. Distribusi Frekuensi Skor Gain Hasil Belajar Kognitif Fisika Peserta Didik pada Kelas Kontrol

\begin{tabular}{cccc}
\hline \multirow{2}{*}{ Kategori } & \multirow{2}{*}{ Interval } & \multicolumn{2}{c}{ Kelas Kontrol } \\
\cline { 3 - 4 } & & Frekuensi & Persentase $(\%)$ \\
\hline Rendah & $\mathrm{G}<0,3$ & 26 & 92,86 \\
\hline Sedang & $0,3 \leq \mathrm{G} \leq 0,7$ & 2 & 7,14 \\
\hline Tinggi & $\mathrm{G}>0,7$ & 0 & 0,00 \\
\hline Jumlah & & 27 & \\
\hline
\end{tabular}

Tabel 9 Hasil Uji T Hasil Belajar Fisika Peserta antara Kelas Eksperimen dan Kontrol

\begin{tabular}{ccccc}
\hline Data & $\mathrm{t}_{\text {hitung }}$ & $\mathrm{Dk}$ & $\mathrm{t}_{\text {tabel }}$ & Keterangan \\
\hline $\begin{array}{c}\text { Hasil belajar fisika kelas } \\
\text { eksperimen dan kontrol }\end{array}$ & 4,906 & 51 & 2,01 & $\begin{array}{c}\text { Terdapat } \\
\text { perbedaan }\end{array}$
\end{tabular}

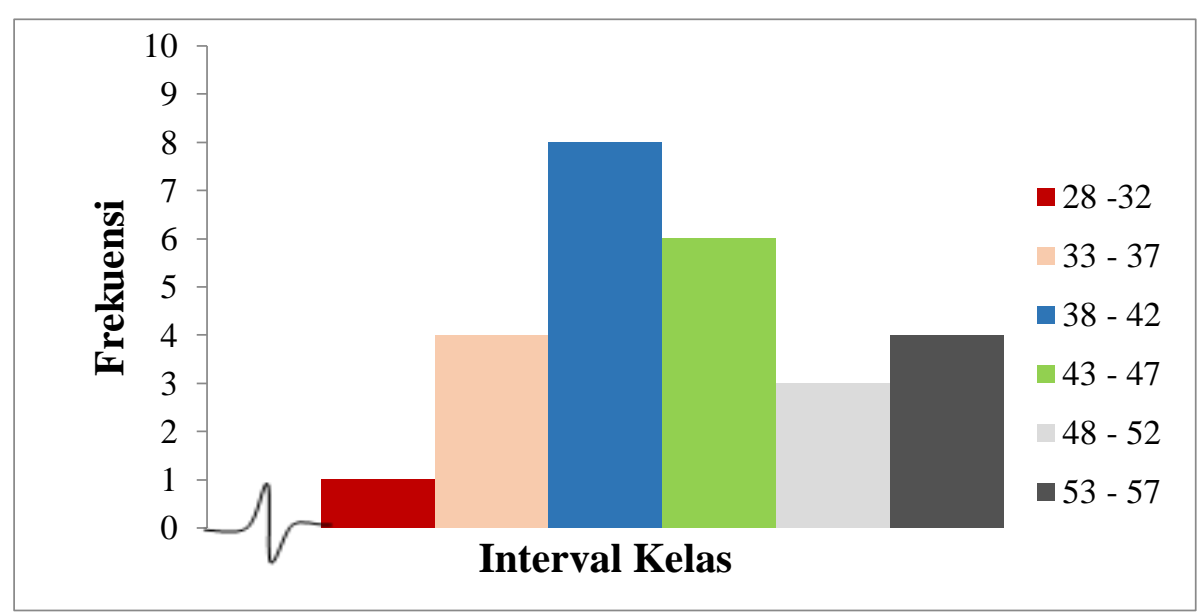

Gambar 1 Histogram Distribusi Pretest Hasil Belajar Kognitif Kelas Eksperimen

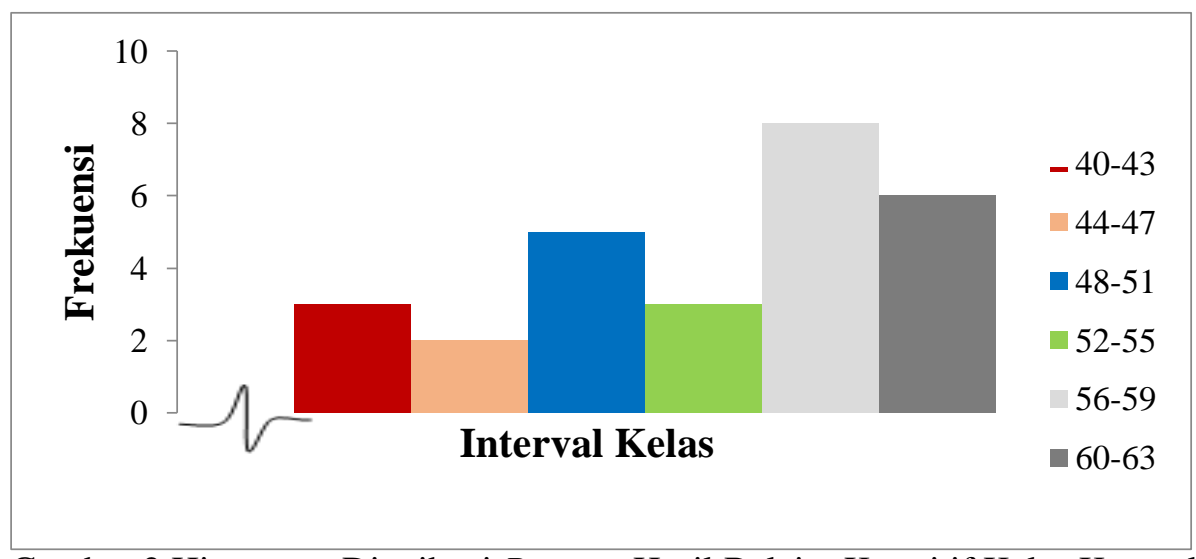

Gambar 2 Histogram Distribusi Posttest Hasil Belajar Kognitif Kelas Kontrol 


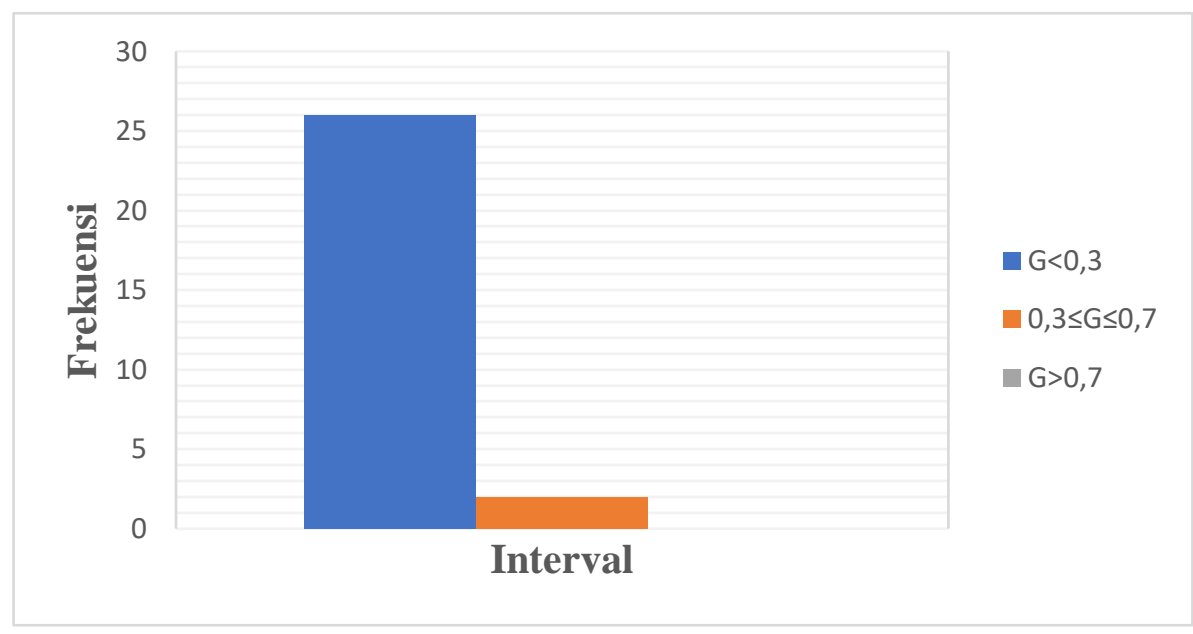

Gambar 3 Histogram Hasil Uji N-gain Terhadap Hasil Belajar Fisika Kognitif Peserta Didik pada Kelas Kontrol

\section{Deskriptif Data}

Berdasarkan hasil tes belajar fisika peserta didik, di bawah ini dikemukakan hasil analisis deskriptif pretest hasil belajar fisika pada kelas eksperimen untuk mengetahui pencapaian awal hasil belajar fisika. Berikut hasil analisisnya dapat dilihat pada tabel 4. Pada tabel 4 dapat diketahui bahwa hasil pretest hasil belajar peserta didik kelas eksperimen menunjukkan skor tertinggi yaitu 57 dan skor terendah yaitu 28 . Adapun skor rata-rata peserta didik yaitu 43,38 dengan standar deviasi 7,56. Sedangkan pada posttest menunjukkan skor tertinggi yaitu 89 dan skor terendah yaitu 65 . Adapun skor rata-rata peserta didik yaitu 79,12 dengan standar deviasi 6,24. Standar deviasi lebih kecil dibandingkan dengan rata-rata artinya bahwa ukuran sebaran data sangat baik.

Distribusi frekuensi pretest hasil belajar kelas eksperimen dapat disajikan dalam bentuk histogram pada Gambar 1. Selanjutnya data posttest disajikan berdasarkan kategori hasil belajar sebagai berikut. Berdasarkan tabel 5 hasil pretest hasil belajar kognitif kelas eksperimen, semua peserta didik berada pada kategori rendah. Selanjutnya tabel distribusi frekuensi posttest hasil belajar kelas kontrol dapat disajikan dalam bentuk histogram sebagai pada Gambar 2.

\section{Uji Normalitas}

Pengujian normalitas bertujuan untuk menyatakan apakah data skor hasil belajar fisika peserta didik sebelum dan setelah diajar dengan menerapkan model pembelajaran Quantum Learning Menggunakan Musik berasal dari populasi yang berdistribusi normal.

Pengujian normalitas dihitung dengan menggunakan uji chi kuadrat. Data yang diuji normalitasnya adalah data pretest dan posttest hasil belajar peserta didik kelas eksperimen dan kontrol. Kriteria hasil perhitungan normalitas yaitu apabila $\chi^{2}$ hitung lebih kecil dari $\chi_{\text {tabel }}^{2}$ dimana daftar $\chi^{2}$ dengan $\mathrm{dk}=(\mathrm{k}-1)$ pada taraf signifikan $(\alpha)=0,05$. Hasil perhitungan dapat dilihat pada tabel 7. Berdasarkan tabel 7 dapat diketahui bahwa $\chi_{\text {tabel }}^{2}$ sebesar 11,0705. Data hasil belajar pretest dan posttest peserta didik pada kelas eksperimen dan kontrol diperoleh nilai $\chi_{\text {hitung }}^{2}>\chi_{\text {tabel. }}$. Dengan demikian, dapat disimpulkan bahwa data pretest dan posttest hasil belajar peserta didik pada kelas eksperimen dan kontrol berdistribusi normal dan memenuhi syarat untuk dianalisis.

\section{Uji Homogenitas}

Uji homogenitas digunakan untuk mengetahui apakah kedua data; pretest dan posttest pada kelas eksperimen dan kontrol homogen atau mempunyai variansi yang sama. Pada kelas eksperimen dan kontrol diperoleh nilai yang signifikan yaitu lebih besar dari 0,05 , artinya data pretest dan posttest hasil belajar fisika peserta didik antara kelas eksperimen dengan kelas kontrol homogen atau mempunyai variansi yang sama. Dengan demikian data 
pretest dan posttest hasil belajar fisika peserta didik memenuhi syarat untuk dilakukan uji-t.

\section{Uji N-Gain}

Pengujian N-Gain bertujuan untuk memberikan gambaran umum peningkatan skor hasil pembelajaran antara sebelum dan sesudah diterapkan model pembelajaran. Tabel 8 menyajikan Hasil uji N-gain hasil belajar peserta didik pada kelas kontrol dengan frekuensi $26(92,86 \%)$ berada pada kategori rendah dan frekuensi $2(7,14 \%)$ berada pada kategori sedang.

\section{Hasil Uji Hipotesis}

Pengujian hipotesis dalam penelitian ini adalah $\mathrm{H}_{0}$ : tidak terdapat perbedaan yang signifikan terhadap hasil belajar fisika peserta didik antara kelas yang menerapkan model pembelajaran Quantum Learning Menggunakan Musik dan kelas yang menggunakan model pembelajaran Konvensional. $\mathrm{H}_{\mathrm{a}}$ : terdapat perbedaan yang signifikan terhadap hasil belajar fisika peserta didik antara kelas yang menerapkan model pembelajaran Quantum Learning Menggunakan Musik dan kelas yang menggunakan model pembelajaran

Konvensional.

Analisis data uji-t yang telah dilakukan dengan syarat data bersifat signifikan apabila $t_{\text {hitung }}$ lebih besar daripada $t_{\text {tabel }}$ diperoleh. Berdasarkan tabel 9 dapat diketahui bahwa $t_{\text {hitung }}$ sebesar 4,906 dengan dk 51 pada taraf signifikan 5\% dan $\mathrm{t}_{\text {tabel }}$ sebesar 2,01. Terlihat bahwa nilai $t_{\text {hitung }}>t_{\text {tabel }}$, dengan demikian hasil uji-t menunjukkan terdapat perbedaan yang signifikan terhadap hasil belajar fisika peserta didik.

\section{SIMPULAN DAN SARAN}

\section{Kesimpulan}

Berdasarkan hasil penelitian dan pembahasan, maka dapat disimpulkan bahwa hasil belajar fisika peserta didik yang diajar dengan menggunakan Model Pembelajaran Quantum Learning Menggunakan Musik berada pada kategori sedang, hasil belajar fisika peserta didik yang diajar dengan menggunakan
Model Pembelajaran Langsung berada pada kategori rendah, dan terdapat perbedaan yang signifikan terhadap hasil belajar fisika pada peserta didik antara kelas yang diajar Model Pembelajaran Quantum Learning Menggunakan Musik dengan kelas yang menggunakan Model Pembelajaran Langsung.

\section{Saran}

Diharapkan kepada pihak Sekolah untuk melengkapi sound system. Diharapkan dari hasil penelitian ini dapat dijadikan bahan masukan dan alat evaluasi serta intropeksi guru dalam memperbaiki kekurangan dalam kegiatan pembelajaran dan sebagai bahan pertimbangan dalam menentukan metode, model, atau strategi yang dapat digunakan untuk meningkatkan hasil belajar fisika peserta didik SMA Negeri 1 Alu.

\section{DAFTAR PUSTAKA}

[1] SMA Negeri 1 Alu, 2019, Nilai ujian semester ganjil Peserta didik kelas XI MIA 1. Tata Usaha SMA Negeri 1 Alu.

[2] DePorter, Bobbi dan Hernacki, Mike.2013. Quantum Learning: Membiasakan Belajar Nyaman dan Menyenangkan. Bandung: Kaifa Learning.

[3] Adityarini, Yunis, dkk. (2013). Penerapan Model Pembelajaran Quantum Learning dengan Media Flashcard untuk Meningkatkan Motivasi dan Hasil Belajar Siswa Kelas $\mathrm{X}$ di SMA NEGERI 1 Purwoharjo-Banyuwangi Tahun Pelajaran 2011/2012 (Pada Pokok Bahasan Animalia). Pancaran.Vol. 2, No. 2, hal 189-199

[4] Kurniawan. 2016. EFEKTIVITAS MUSIK KLASIK (MOZART) UNTUK MENURUNKAN KEJENUHAN BELAJAR SISWA KELAS XI SMAN 4 YOGYAKARTA. Jurnal Bimbingan dan Konseling. Vol. 2 (5). 1-10.

[5] Cahyo Dwi, Andita, Desyandri dengan judul penelitian PENGARUH PENGGUNAAN MUSIK TERHADAP KONSENTRASI BELAJAR ANAK SEKOLAH DASAR. 
[6] Hidayat. 2016. Penggunaan media pembelajaran melalui musik instrumental untuk meningkatkan motivasi belajar peserta didik kelas XI di Madrasah Aliyah Bustanul Makmur Banyuwangi. Universitas Islam Negeri Maulana Ibrahim Malang.

[7] Prakoso, Yans Al dkk. (2017), Pengaruh Musik Klasik Terhadap Hasil dan Aktivitas Belajar Matematika siswa Kelas VII di SMPN 2 Kota Bengkulu. Jurnal Penelitian Pembelajaran Matematika Sekolah (JP2MS), Vol. 1, No. 1

[8] Kemendikbud. (2014). Materi Pelatihan Guru Implementasi Kurikulum 2013 Fisika SMA. Jakarta: Badan Pengembangan Sumber Daya Manusia Pendidikan dan Kebudayaan dan Penjaminan Mutu Pendidikan Kemendikbud.

[9] Sugiyono. (2017). Metode Penelitian Pendidikan Pendekatan Kuantitatif Kualitatif R\&D. Bandung: Alpha Beta

[10] Susetyo, Budi. (2017). Metode penelitian pendidikan: pendekatan kuantitatif, kualitatif dan R\&D. Bandung: Alpha Beta.

[11] Dewi, P.E. (2017). Efektivitas Modul dengan Model Inkuiri untuk Menumbuhkan Keterampilan Proses Sains Siswa pada Materi Kalor , Jurnal Keguruan dan ilmu Tarbiyah, ISSN: 25797964 